\title{
Differing importance of salinity stratification and freshwater flow for the recruitment of apex species of estuarine fish
}

\author{
Gregory P. Jenkins ${ }^{1, *}$, Daniel Spooner ${ }^{2}$, Simon Conron ${ }^{3}$, John R. Morrongiello ${ }^{1,4}$ \\ ${ }^{1}$ Department of Zoology, University of Melbourne, Parkville, VIC 3010, Australia \\ ${ }^{2}$ Gladstone Ports Corporation, PO Box 259, Gladstone, QLD 4680, Australia \\ ${ }^{3}$ Fisheries Management and Science, Fisheries Victoria, Department of Environment and Primary Industries, PO Box 114, \\ VIC 3225, Australia \\ ${ }^{4}$ Australian Rivers Institute, Griffith University, Nathan, QLD 4111, Australia
}

\begin{abstract}
Estuarine fish live in a highly dynamic environment where recruitment variability is a key determinant of population trajectory. Environmental requirements for successful recruitment may differ between co-occurring species, and therefore species may be advantaged or disadvantaged under climate change. Recruitment variability in black bream Acanthopagrus butcheri and estuary perch Macquaria colonorum in estuaries along the coast of western Victoria, south-eastern Australia, was determined from the age structure of the populations. Recruitment was found to be episodic in both species, with the populations dominated by a few year classes however, abundant year classes differed between species. Historical freshwater flows were found to be similar across estuaries, reflecting broad-scale rainfall. In contrast, water column stratification (difference between surface and bottom salinity) over a $7 \mathrm{yr}$ period varied widely amongst estuaries. In general, recruitment of black bream was negatively correlated with freshwater flow and positively correlated with the level of stratification. In contrast to black bream, significant correlations for recruitment of estuary perch were negatively related to stratification and positively related to flows. Thus, although both species spawn in the spring and early summer, they have different environmental requirements in terms of flow and stratification for successful recruitment. This means that high inter-annual variability in flow is required for both species to experience favourable environmental conditions over time. Furthermore, the climate change scenario of significantly reduced flows in the Victorian region may mean that in many estuaries the conditions will be more favourable for the recruitment of black bream than for estuary perch.
\end{abstract}

KEY WORDS: Year-class strength · Salinity · Estuarine stratification · Freshwater flow $\cdot$ Black bream $\cdot$ Acanthopagrus butcheri $\cdot$ Estuary perch $\cdot$ Macquaria colonorum

\section{INTRODUCTION}

Estuaries have complex and variable salinity structure that depends on the interaction of freshwater flows and factors such as topography, bathymetry and estuary mouth opening and closing (Roy et al. 2001, Potter et al. 2010). Freshwater flow is the most important factor generating variation in salinity structure in estuaries (Kurup et al. 1998, Kimmerer 2002). Estuarine fish populations tend to respond to this high variation in freshwater flow and salinity structure by showing high (often episodic) recruitment variability (Morison et al. 1998, Staunton-Smith et al. 2004, Walsh et al. 2010). Depending on species and location, high freshwater flows may favour recruitment (Kimmerer et al. 2001, North \& Houde 
2003, Staunton-Smith et al. 2004, North et al. 2005, Robins et al. 2005) or be detrimental to recruitment (Deegan 1990, Rulifson \& Manooch 1990, Sarre \& Potter 2000, Shoji et al. 2006). This means that if there is a long-term increasing or decreasing trend in freshwater flows, some estuarine fish species may be favoured over others.

Australia has the most spatially and temporally variable rainfall and runoff of any continent (Arthington \& Pusey 2003, Gillanders et al. 2011). Salinity structure in southern and south-eastern Australian estuaries shows further variability due to the fact that many are intermittently closed by sand bars (Roy et al. 2001, Chuwen et al. 2009, Gillanders et al. 2011), with an estimated $45 \%$ of estuaries in southeastern Australia falling into this category (Griffiths \& West 1999). This high variability in flow and salinity structure may explain why many of the examples of estuarine-dependent fish with episodic recruitment in the scientific literature come from the Australian continent (Morison et al. 1998, StauntonSmith et al. 2004, Halliday et al. 2008, Jenkins et al. 2010, Walsh et al. 2010).

Two species that show episodic recruitment variation and which co-occur in estuaries of south-eastern Australia are the black bream Acanthopagrus butcheri (Morison et al. 1998, Jenkins et al. 2010) and the estuary perch Macquaria colonorum (Walsh et al. 2010). Both are iconic estuarine-dependent fish species that are apex predators and are highly sought after by recreational and commercial fishers. In Victoria, south-eastern Australia, spring is considered to be the primary spawning period for both black bream (Newton 1996, Nicholson et al. 2008, Jenkins et al. 2010) and estuary perch (Walsh et al. 2010, 2011). The spawning habitat of the 2 species, however, may be quite different. Black bream egg and larval abundance and survival is greatest at intermediate salinities (10 to 20) (Newton 1996, Haddy \& Pankhurst 1998, 2000, Nicholson et al. 2008) and often in association with strong salinity stratification (salt wedge development) (Nicholson et al. 2008, Williams et al. 2012, 2013). These environmental conditions mean that under low-flow conditions, spawning may occur well upstream in the estuary (Sakabe et al. 2011, Williams et al. 2013). Although less is known about the environmental requirements for spawning of estuary perch, it is generally thought that this species moves downstream and spawns in the lower reaches of estuaries (Douglas 2010, Walsh et al. 2011). Recent research has indicated that downstream spawning migrations are triggered by increased freshwater flow (Walsh et al. 2013). These potential differences in spawning habitat between the 2 species suggest different environmental requirements for successful recruitment.

There is very high rainfall variability in southeastern Australia that is influenced by at least 3 major atmospheric-oceanic drivers: the El Niño-Southern Oscillation (ENSO), sea surface temperature anomalies in the Indian Ocean northwest of Australia, and the Southern Hemisphere extra-tropical circulation (CSIRO 2010, Chiew et al. 2011). In the future, a longterm decline in rainfall in the southern part of the south-east Australian region (including the State of Victoria) is predicted, which will primarily occur in the winter when a significant proportion of the annual rainfall occurs (CSIRO 2010, Chiew et al. 2011, Hobday \& Lough 2011). In addition to a reduction in overall rainfall, rain may tend to occur in more intense events, interspersed with an increasing proportion of dry days, signifying more extreme weather fluctuations (CSIRO 2007). The projected long-term decrease in freshwater flows to estuaries may have major implications for estuarine-dependent fish depending on their environmental requirements for spawning and recruitment. The effects of climate change on freshwater flow and salinity stratification with consequent impacts on estuarine fish may be exacerbated by human activities such as water abstraction, diversion and flow alteration (Kimmerer 2002, Scavia et al. 2002), as well as artificial opening and closing of estuary entrances (Griffiths 1999).

The current study has 2 major aims. The first aim is to determine how the recruitment of the black bream $A$. butcheri and the estuary perch $M$. colonorum relates to freshwater flow and salinity stratification in Victorian estuaries. The second aim is to use this information to make predictions in relation to the potential effect of climate change on the recruitment of these species in the future. We hypothesise that differing environmental requirements for spawning may lead to differing future outcomes for recruitment of these species under climate change.

In undertaking ageing for the present study, we realised that the standard ageing technique previously used for black bream did not take into account the spring spawning period. The notional year class of $0+$ fish using the standard ageing method actually represented the year after the spawning year (Morison et al. 1998). This meant that it was necessary to lag our recruitment estimates by $1 \mathrm{yr}$ when comparing with flow and stratification data. In our earlier study of black bream recruitment in Gippsland Lakes, Victoria, pre-existing ageing data was used that was not adjusted for the spring spawning period (Jenkins et al. 

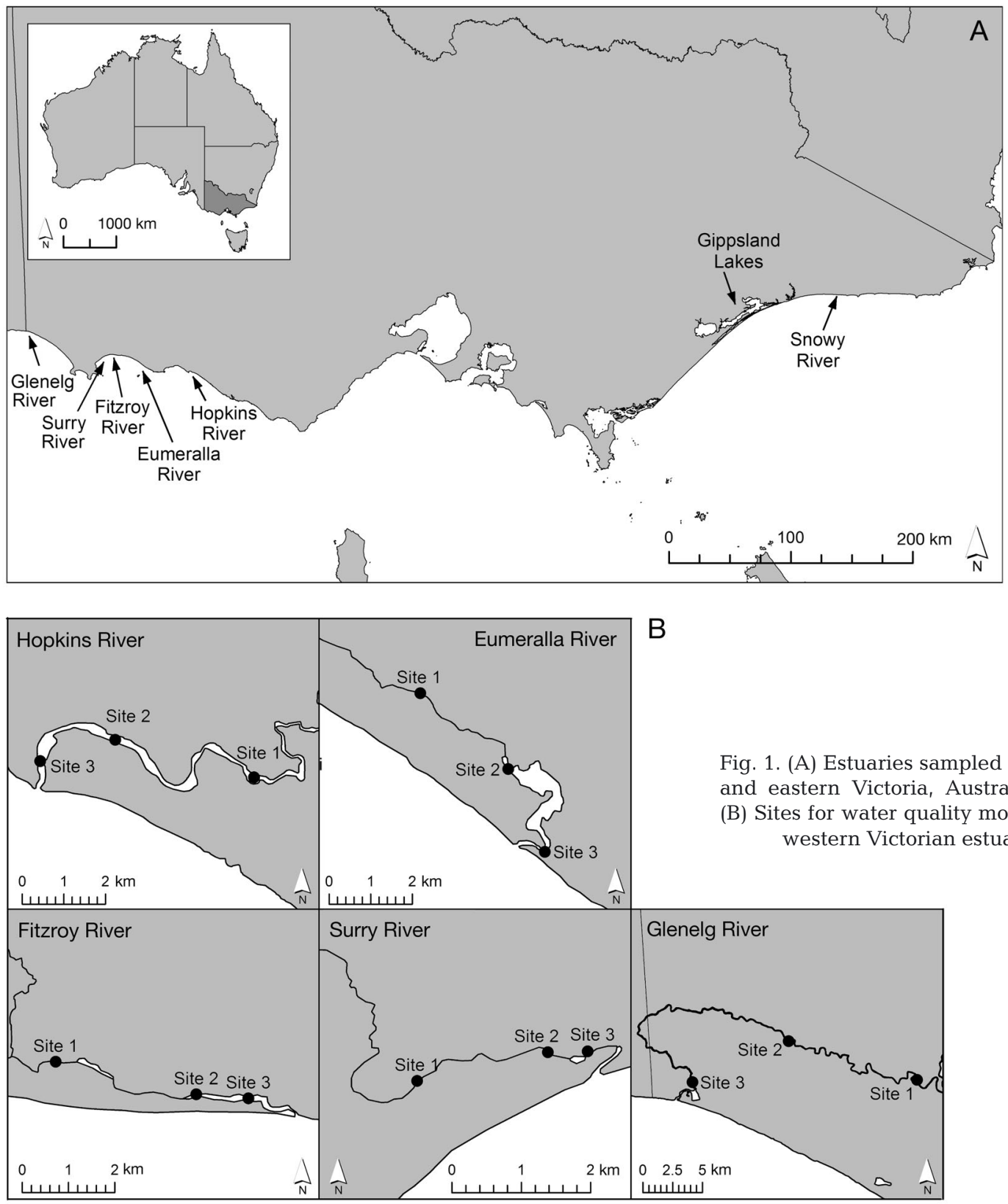

2010). In the present paper we present a re-assessment of the results from Jenkins et al. (2010) and discuss these in the light of results from the current study.

\section{MATERIALS AND METHODS}

\section{Study area}

The primary study area was western Victoria due to the presence of a range of estuaries with populations of both black bream and estuary perch and the availability of water quality data that included depthstratified salinity. In western Victoria, the Glenelg, Surry, Fitzroy, Eumeralla and Hopkins River estuaries were sampled (Fig. 1). The estuaries varied greatly in their topography and bathymetry, ranging from a relatively linear, larger and longer estuary such as the Glenelg Estuary, to linear estuaries that were smaller, shorter and shallower such as the Surry and the Fitzroy Estuaries. The Eumeralla Estuary had broader lagoon and fringing wetland systems near the mouth, and the Hopkins Estuary was characterised by deep pools. These estuaries tend to be highly stratified and are intermittently closed at 
the mouth under low-flow conditions (Barton et al. 2008). The pattern of entrance opening and closing is irregular and is often managed artificially using earth moving equipment. There tends to be a distinct hydrological cycle where estuaries are highly stratified in the summer and autumn with the potential for low dissolved oxygen in bottom waters, followed by increased flows and reduced stratification and increased dissolved oxygen in the winter and spring (Newton 1996). The Glenelg River had the longest estuary length and largest catchment, and was the only regulated river studied in western Victoria (Table 1). Additional samples were collected from the Snowy River estuary between the confluence of the Snowy and Brodribb Rivers and the mouth (Fig. 1, Table 1); however in this case the only physical time-series data available were for freshwater flow. The Snowy River flow is highly regulated by dam release near the source at Lake Jindabyne, and the mouth entrance is permanently open (Barton et al. 2008).

\section{Fish sampling}

Black bream and estuary perch were sampled with research mesh (gill) nets deployed at 2 sites in each estuary on each sampling day in early 2011 and 2012 (Table 1). On each sampling day, sampling of the 2 sites was conducted at both dawn and dusk, and 4 experimental mesh nets were set for each combination of site and time of day. Mesh nets were $50 \mathrm{~m}$ long with a 3 m drop, consisting of 4 equal length monofilament panels of $3.8,6.3,8.8$ and $11.3 \mathrm{~cm}$ mesh size. Mesh nets were set for a period of $4 \mathrm{~h}$ either side of dawn and dusk. Supplementary samples were also collected with a research seine net from the Glenelg and Hopkins estuaries in 2012 to increase the sample size of black bream (Table 1). The multifilament mesh research seine was $50 \mathrm{~m}$ long with a $2 \mathrm{~m}$ drop, with $10 \mathrm{~mm}$ mesh size. The seine net was set in a circle from the shore and retrieved back to the shore for sorting. Additional age data came from angler-collected samples of black bream and estuary perch from the Glenelg and Hopkins estuaries collected over the past decade (Table 2) that had been rou- tinely aged based on otolith annual increments for use in stock assessments. These samples were provided by angler diarists (recreational anglers who recorded catch details in diaries for stock assessment purposes) and research anglers (recreational anglers using prescribed methods to provide data for stock assessment purposes) working under the direction of the State Fisheries agency (Fisheries Victoria) that also analysed the data. This sampling represented hundreds of hours of fishing each year by multiple anglers in each estuary (Table 2). Full retention of black bream and estuary perch by mesh and seine nets was considered to occur by age 1, and both species were considered fully susceptible to angling by age 2 .

\section{Age analysis}

In the laboratory, otoliths were dissected from the fish and stored dry for ageing. Opaque zones in the otoliths of black bream (Morison et al. 1998) and estuary perch (Walsh et al. 2010) have been validated as forming annually. The method, validation and precision of ageing transverse sections of black bream otoliths is described by Morison et al. (1998). In the present study, the same method was applied to ageing estuary perch. 


\section{Physical data}

The Glenelg Hopkins Catchment Management Authority recorded depth-stratified measurements of physical and chemical variables in western Victorian estuaries at approximately monthly intervals from late 2003 to 2010 . The 3 sample sites closest to the estuary mouth were analysed (Sites 1, 2 and 3 representing upper, middle and lower sites respectively; Fig. 1) as these are closest to likely spawning areas of black bream and estuary perch.

Surface and bottom salinities were averaged over the months of July to December (the approximate spawning season). An index of water column stratification was then estimated by subtracting the average surface salinity from the average bottom salinity to give an annual estimate (Jenkins et al. 2010) for each estuary section and the estuary as a whole.

Flow (discharge, $\times 10^{6} \mathrm{l} \mathrm{d}^{-1}$ ) data are recorded for each river system entering the estuaries and are stored at the Victorian Water Measurement Information System (http://data.water.vic.gov.au/monitoring. htm). Daily flow data over the period of the present study were extracted, and annual mean daily flows (MDF) and the flow level exceeded 10\% of the time (P10, measure of high-flow hydrology) were calculated for the July to December spawning period.

\section{Data analyses}

Recruitment variability was estimated from the age structure of the sampled black bream and estuary perch using a generalised linear model (GLM) formulation (see Morrongiello et al. 2014 for details) of the catch-curve regression method proposed by Maceina (1997). We assumed that deviation from the catch-curve regression was a reflection of variable recruitment (Staunton-Smith et al. 2004, Morrongiello et al. 2014), with large positive and negative residuals representing strong and weak year classes respectively. We adopted a 2-stage process to analyse catch-at-age-data for each site: first, we produced base models to describe recruitment variability that accounted for total mortality and multiple sampling events; second, we added environmental variables to these base models to test whether recruitment variability was related either linearly or curve-linearly to flow and/or salinity.

As the underlying data consist of counts (i.e. number of fish caught for a given year class), we first applied Poisson, then - if overdispersion was present-negative binomial GLMs for each site. Site-specific models always included fish age (continuous) and where necessary sampling year (factor) to account for repeated observations of the same year class and for variation in sampling effort. We tested whether estimates of population mortality (age slope) where constant through time by fitting an age $\times$ sample year interaction. This term allowed us to correct for any sample-specific biases in selectivity or time-varying mortality rates and thus assume that observed patterns in age structures are determined mainly by recruitment variation (King 2007).

Pearson residuals from the GLM catch curve were calculated for each sampling year-site combination from the models above and then plotted together along with the mean residual time series to provide a graphical representation of a site's recruitment index. Based on inspection of age-frequency graphs, catch curves were calculated for black bream and estuary perch that were at least 1 yr old for netting and at least 2 yr old for angling methods. Although selectivity for the smaller fish was different for the netting and angling methods, it was still possible to combine the data for year classes fully retained by the netting and fully susceptible to the angling methods. The oldest fish caught at each site was used as an upper age class ceiling for each sample year; missing age classes in a given sample were assumed indicative of weak year-class strength, assigned zero catch and retained for analysis (Morrongiello et al. 2014). The Snowy River black bream and estuary perch catches were truncated (at max. age 12 and 8 respectively) due to the extreme, but unreplicated maximum ages of fish at this site (see Figs. 2 to 4 ), which resulted in unreliable estimates of increasingly historic recruitment events.

Only freshwater flow data spanned each site's full recruitment time series. We therefore compared models with and without linear and quadratic flow terms across all available year classes to explore whether flow was a long-term driver of recruitment variation. For the period 2004 onwards, we compared a series of models including flow and/or one of the salinity variables. Collinearity between flow and salinity was checked by examining the tolerance value for the analysis (Quinn \& Keough 2002). The analysis was excluded if the tolerance value was less than 0.1 (Quinn \& Keough 2002). The Akaike information criterion (AIC) was used to compare competing models (Burnham \& Anderson 
2002), with values re-scaled as the difference between each model and the model with the lowest AIC ( $\triangle \mathrm{AIC})$.

In accordance with the standard ageing method, the estimated year class to which an individual fish belonged is normally estimated as the year that the first otolith increment was formed. However, for both black bream and estuary perch, this is likely to have occurred at approximately 12 mo after spawning (i.e. spawning occurs in spring and the first increment is formed the following spring). Therefore, when analysing the possible effects of freshwater flow and stratification on spawning and egg and larval survival, the estimate of year-class strength was lagged by 1 yr.

\section{RESULTS}

\section{Age structure}

\section{Black bream}

Black bream showed variable age structure in the Glenelg Estuary, with a strong year class in 2006 and moderately strong year classes in 2003, 2000 and 1998 (Fig. 2). More recent year classes (2008 to 2010) also appeared to be moderately strong (Fig. 2). As in the Glenelg Estuary, black bream in the Surry and Fitzroy Estuaries also exhibited a dominant year class in 2006 (Fig. 2). There was a moderate year class in 2009, and the 2003 and 2000 year classes were also in evidence in both estuaries (Fig. 2). The Surry River was notable for the large number of $0+$ age fish caught in 2011 (Fig. 2). The age structure of black bream in the Eumeralla Estuary showed a different pattern from the 3 estuaries to the west, with strong year classes in 2010 and 2005, and moderate year classes in 2009, 2008 and 2004 (Fig. 2). The age structure of black bream from the Hopkins Estuary in 2012 showed strong year classes in 2009, 2008, 2005, 2000 and 1999 (Fig. 3). Sampling in the Hopkins Estuary prior to 2012 indicated that there was a strong year class in 1999, and sampling in 2004 indicated that the 2000 year class was also prominent, while sampling in 2003 indicated strong year classes from 1994 to 1996 and the presence of older fish from the early to mid-1980s (Fig. 3). The age structure of black bream from the Snowy River showed a dominance of recent year classes including 2010, 2009, 2007 and 2005, as well as a few older individuals from year classes in the 1980s (Fig. 3).

\section{Estuary perch}

Over both sampling years in the Glenelg Estuary, estuary perch age structure (as sampled by research netting) showed episodic recruitment, with most of the fish coming from the 2008 and 2005 year classes and with sampling in 2012 also indicating a strong cohort of $0+$ age recruits (Fig. 4). Age structure of estuary perch in the Hopkins Estuary sampled in 2011-2012 showed high variability but not to the extent seen in the Glenelg Estuary (Fig. 4). Recent year classes since 2007 were relatively strong, as were the 2004 and 2005 year classes (Fig. 4). Older year classes were dominant in 2000 and 1996 (Fig. 4). Sampling of estuary perch from the Hopkins Estuary by angling prior to 2011 indicated that in addition to 2005, there were strong year classes in 2003-2004, 1999-2000 and 1996 (Fig. 4). Individuals from year classes from the early to mid-1980s were also present (Fig. 4). The age structure of estuary perch sampled from the Snowy Estuary by research netting was dominated by the 2009 year class (Fig. 4).

\section{Freshwater flow}

MDF to the 6 estuaries from July to December varied widely, with the highest volumes of water entering the Snowy, Glenelg and Hopkins Estuaries, and relatively low flows entering the Surry, Fitzroy and Eumeralla Estuaries (Fig. 5). MDFs in all estuaries were generally higher from 1980 to 1995 compared to the period since 1995, particularly in the larger Glenelg, Hopkins and Snowy Rivers (Fig. 5), reflecting the extended drought that occurred in this period. MDF also varied substantially on a 1 to $3 \mathrm{yr}$ scale; for example, in the past decade MDFs in the western estuaries were higher in 2000-2001, 2004, 2007 and 2009-2010 (Fig. 5). Flows in all rivers were significantly correlated amongst each other $(p<0.05)$. Highest correlations were between rivers in western Victoria (Pearson's $r=0.811-0.944)$, while correlations between flow in the Snowy River and that in western rivers were lower $(\mathrm{r}=0.353-0.508)$. Standard errors indicated that within an individual estuary, years of higher MDF also had higher flow variation (Fig. 5), showing the influence of flood events in high flow years. Qualitatively similar patterns were observed for high flow conditions (P10; data not shown). 


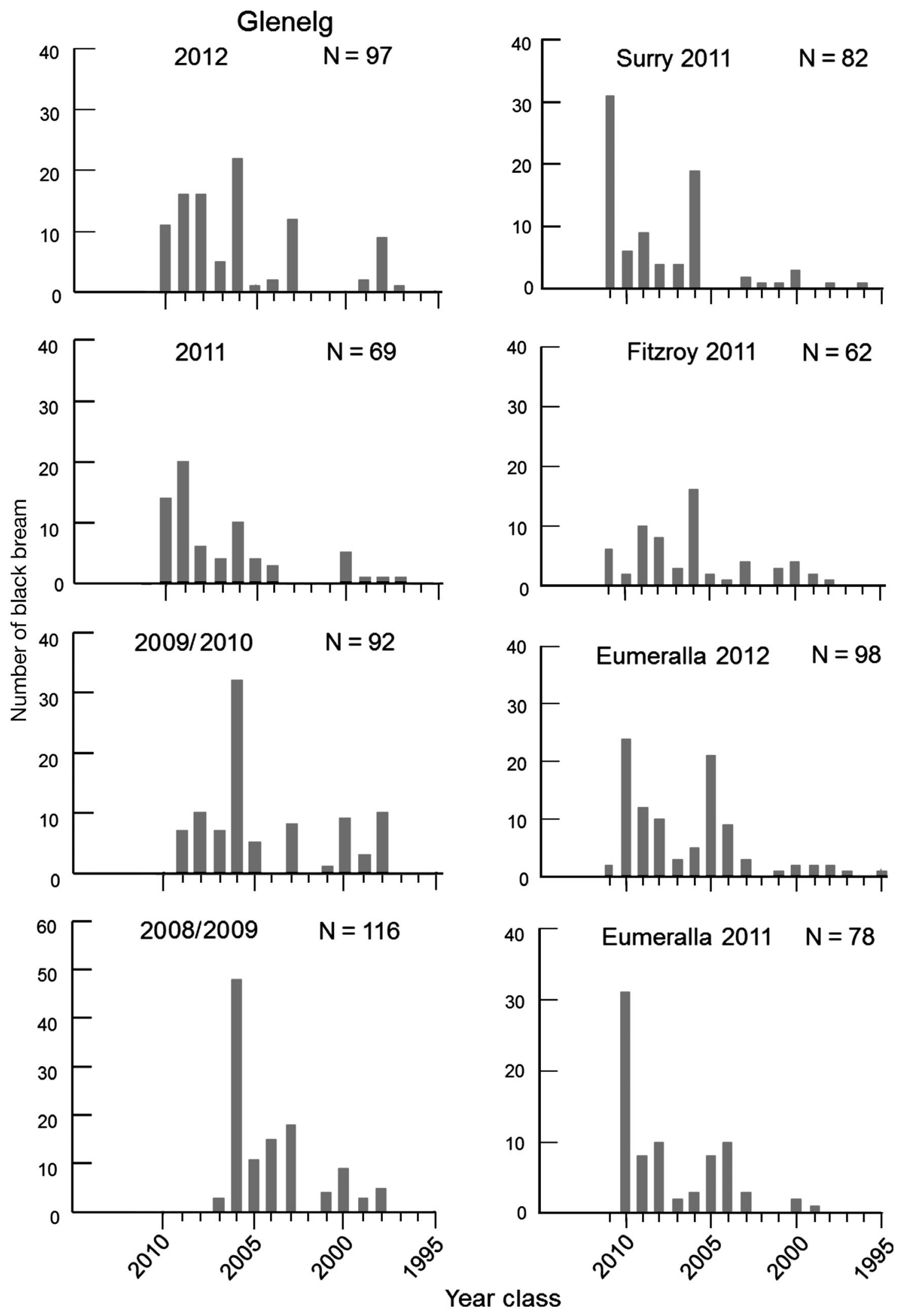

Fig. 2. Age structure of black bream Acanthopagrus butcheri from the Glenelg Estuary sampled by netting (2011-2012) and angling (2008-2010), and from the Surry, Fitzroy and Eumeralla Estuaries sampled by netting. Note different scales of $y$-axes 


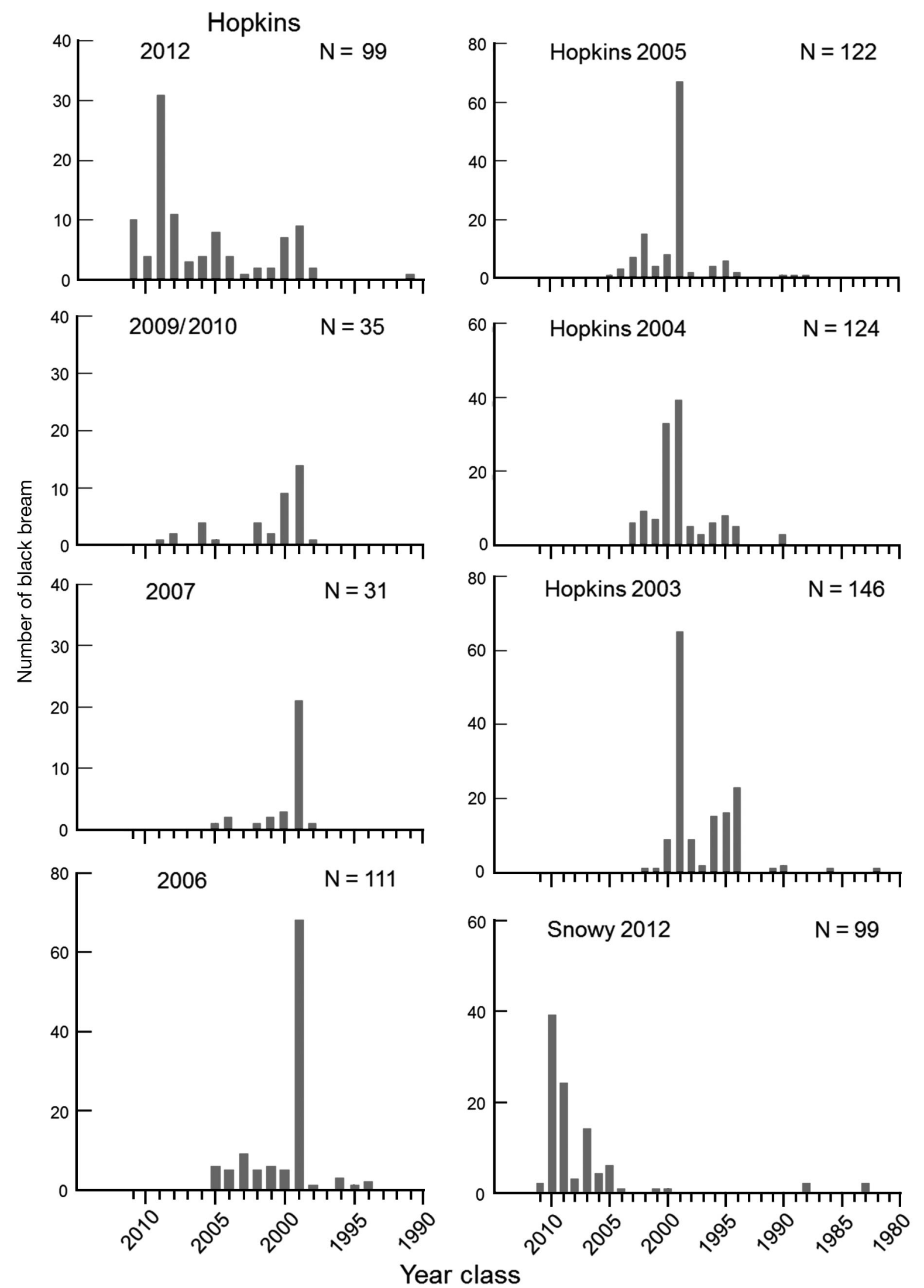

Fig. 3. Age structure of black bream Acanthopagrus butcheri from the Hopkins River sampled by netting (2012) and angling (2003-2010), and from the Snowy River sampled by netting. Note different scales of $y$-axes 


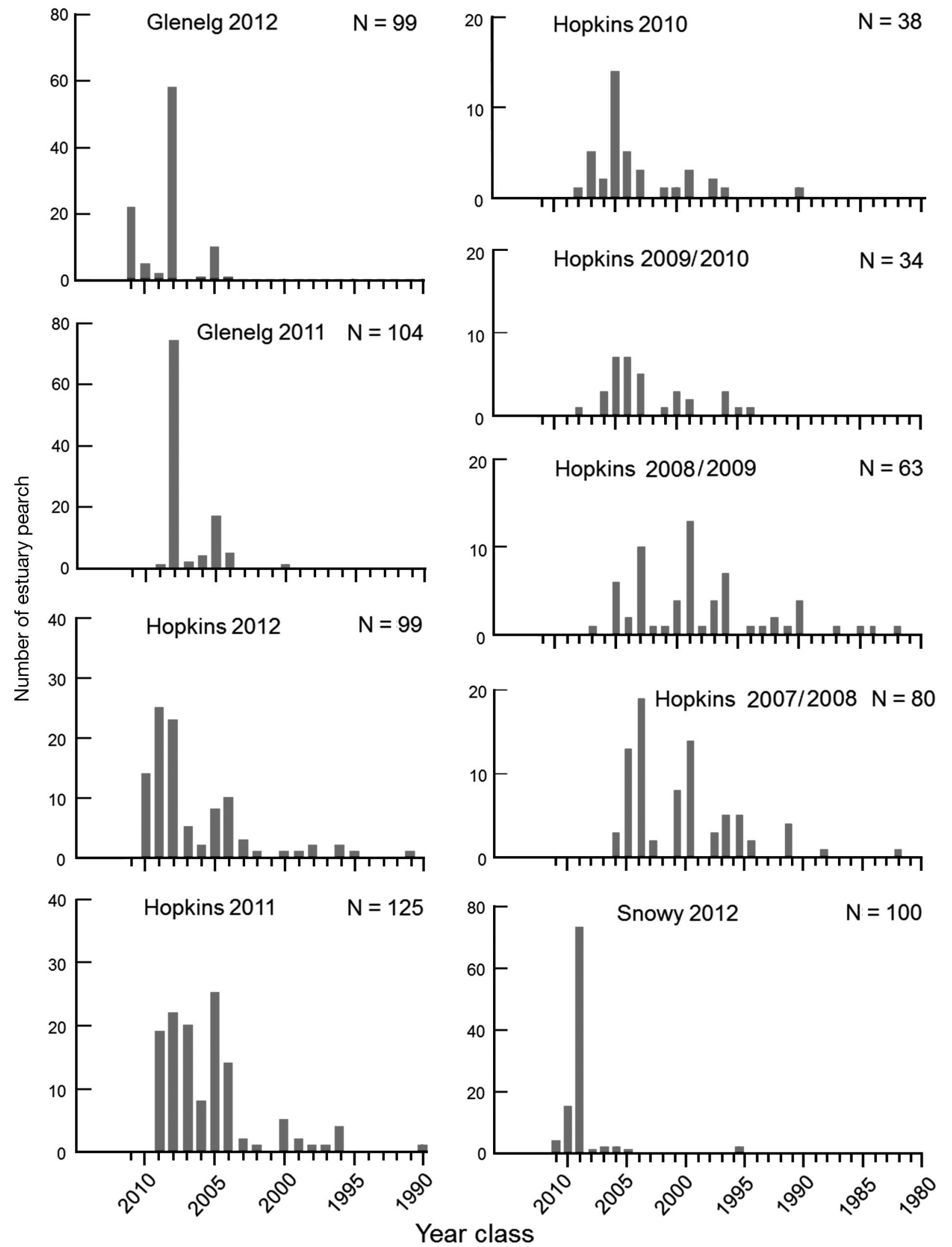

Fig. 4. Age structure of estuary perch Macquaria colonorum from the Glenelg Estuary sampled by netting, from the Hopkins Estuary sampled by netting (2010-2012) and angling (2007/2008-2009/2010), and from the Snowy Estuary sampled by netting. Note different scales of $y$-axes 

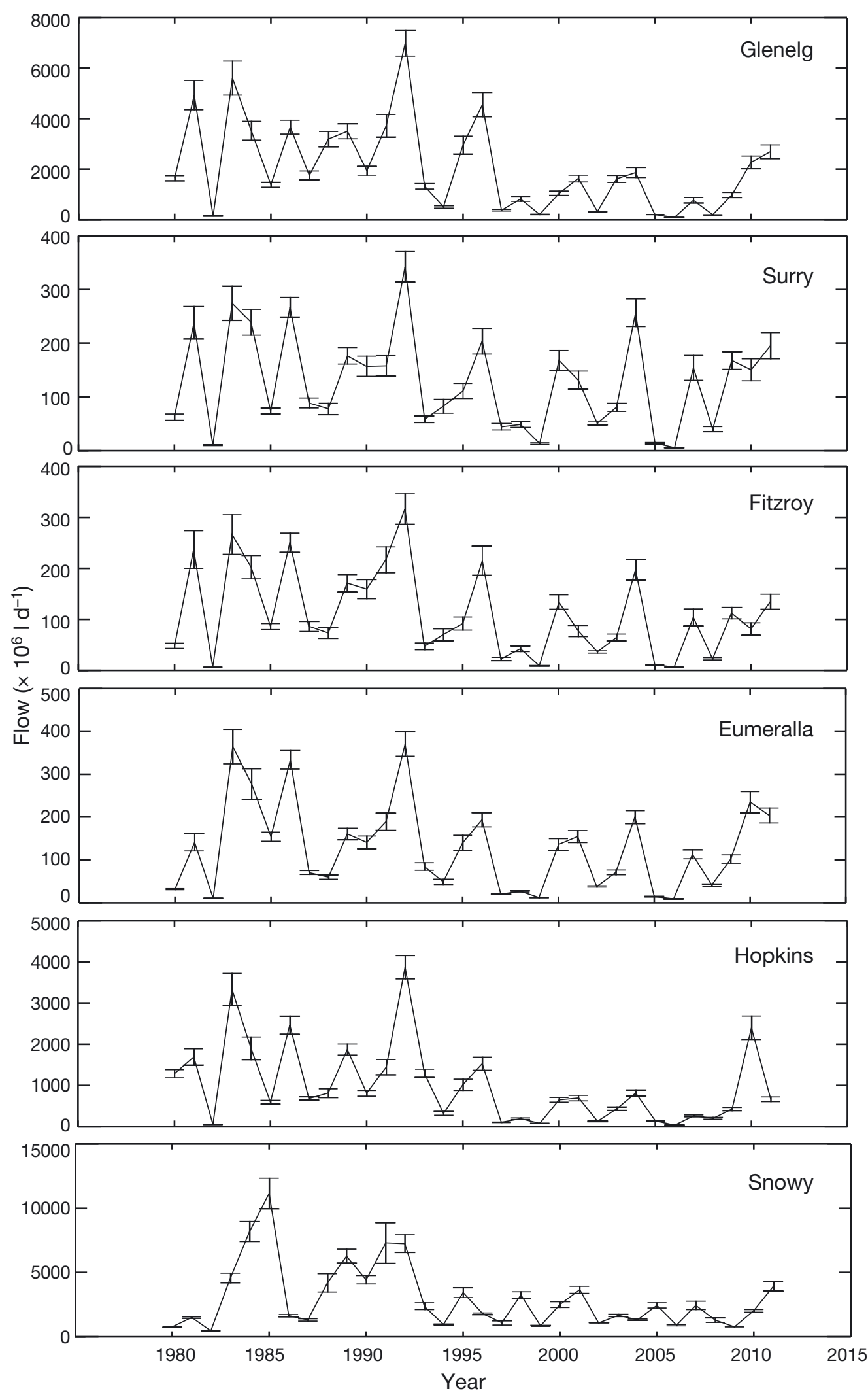

Fig. 5. Daily average $( \pm \mathrm{SE})$ freshwater flow from July to December for rivers entering 6 Victorian estuaries over the period 1980 to 2011. Note different scales of $y$-axes 

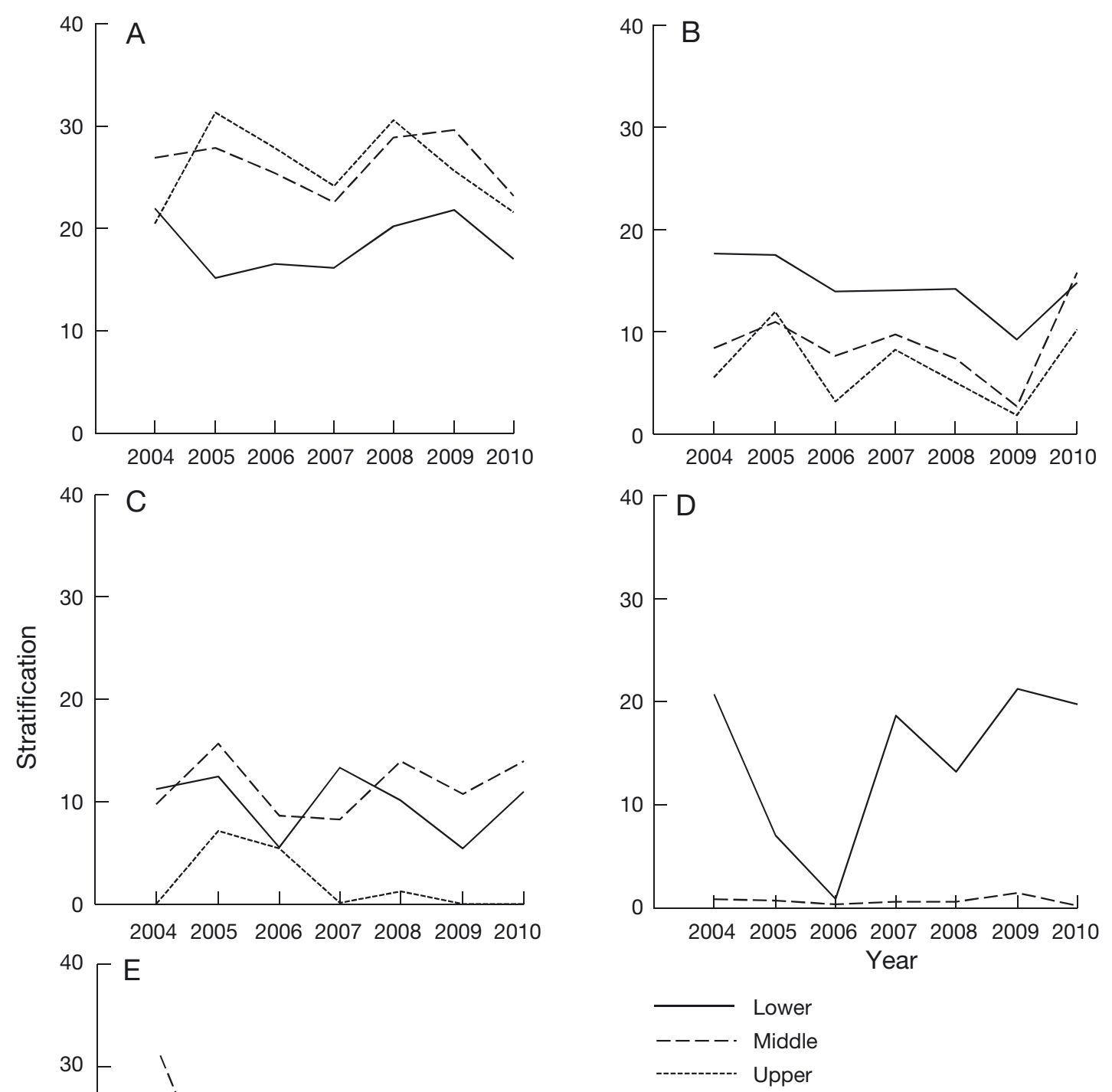

Fig. 6. Stratification (the difference between average surface and bottom salinities for the July to December period) at lower, middle and upper sites over the period 2004 to 2010 for the (A) Glenelg, (B) Surry, (C) Fitzroy,

(D) Eumeralla and (E) Hopkins Estuaries

\section{Salinity stratification}

Salinity stratification in the Glenelg Estuary was quite strong, especially at the middle and upper sites (Fig. 6A). Stratification at the upper site showed yearly variation, with maxima in 2005 and 2008, and minima in 2004, 2007 and 2010 (Fig. 6A). At the mid- dle and lower sites, 2009 was a year of relatively high stratification (Fig. 6A). Stratification was less well developed in the Surry Estuary compared to the Glenelg Estuary, particularly at the middle and upper sites (Fig. 6B). Stratification tended to be relatively stronger in 2005 and 2010 and comparatively weak in 2009 (Fig. 6B). Like the Surry Estuary, salin- 
ity stratification was not strongly developed in the Fitzroy Estuary, particularly at the upper site (Fig. 6C). The annual trend in stratification was highly variable amongst sites, although 2005 showed relatively high stratification at all sites (Fig. 6C). The Eumeralla Estuary at the upper site was too shallow for a meaningful comparison of surface and bottom salinities. At the middle site, the salinity in the water column was essentially homogeneous, but stratification was highly variable at the lower site (Lake Yambuk) (Fig. 6D), ranging from moderately strong stratification in 2004, 2007 and 2009-2010 to no stratification (homogeneous salinity) in 2006 (Fig. 6D). Stratification in the Hopkins Estuary showed considerable variation amongst years, most notably at the middle site (Fig. 6E). Stratification was well developed in 2004 and 2009, but was relatively weak in 2006 at the middle site and 2005 and 2006 at the lower site (Fig. 6E).

\section{Recruitment variation}

All Poisson models for black bream and estuary perch suffered from overdispersion (theta range 2.25-31.34; models not shown), so we used negative binomial GLMs for all catch curve regression analyses. For both species, the simpler age + sample year model formulation was favoured over the more complex age $\times$ sample year at 3 of 5 estuaries with multiple samples (but not black bream in the Glenelg or Eumeralla Estuary; $\triangle \mathrm{AIC}$ for simpler model $=1.91$ and 0.67 respectively).

Catch curve analysis for black bream in the 6 estuaries showed highly variable recruitment (Figs. 7 \& 8). In the Glenelg Estuary, peaks in 0+ age recruitment occurred in 2009, 2006, 2003, 2000 and 1998 (Fig. 7A). A very low level of recruitment was recorded in potentially 2011 and in 2001-2002 (Fig. 7A). In the Surry Estuary, the analysis indicated very high $0+$ age recruitment in 2006, with moderate recruitment also in 2009, 2003, 2000, 1998 and 1996 (Fig. 7B). Recruitment was very low in 2005 and 2004 (Fig. 7B). In the Fitzroy Estuary, recruitment was again very high in 2006, and moderately high in 2008-2009, 2003 and 2000-2001 (Fig. 7C). Recruitment was very low in 2010 and 2002 (Fig. 7C). In the Eumeralla Estuary, high 0+ age recruitment occurred in 2010, 2004-2005 and 1999-2000, while a low level of recruitment occurred in 2007 and 2001-2002 (Fig. 8A). In the Hopkins Estuary, there was very strong $0+$ age recruitment in 2009 and 1999 and potentially 1982 (only one observation for the latter), and moderately strong recruitment in 2005-2006,
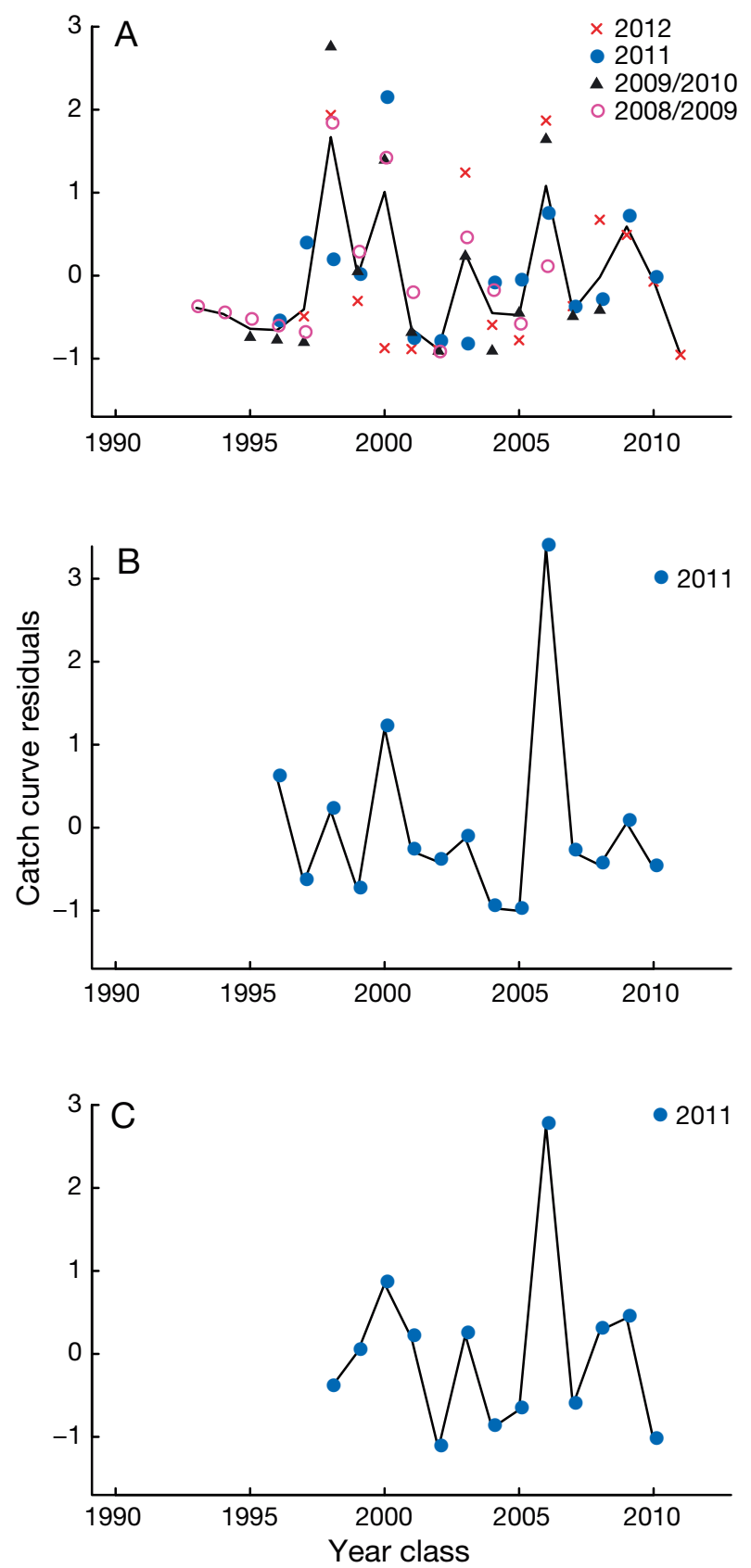

Fig. 7. Pearson residuals (data points) and average of the residuals (solid line) from the negative binomial catch curve regression of the age structure of black bream Acanthopagrus butcheri in the (A) Glenelg, (B) Surry and (C) Fitzroy Estuaries

1994-1995 and 1990 (Fig. 8B). Relatively low recruitment occurred in 2010, 2007, the early 2000s, 1997 and 1991-1993 (Fig. 8B). In the Snowy Estuary the analysis indicated high 0+ age recruitment in 20092010, 2007, 2005, and 2000-2001 (Fig. 8C). A low level of recruitment was estimated to have occurred in 2008, 2006 and 2003-2004 (Fig. 8C). 

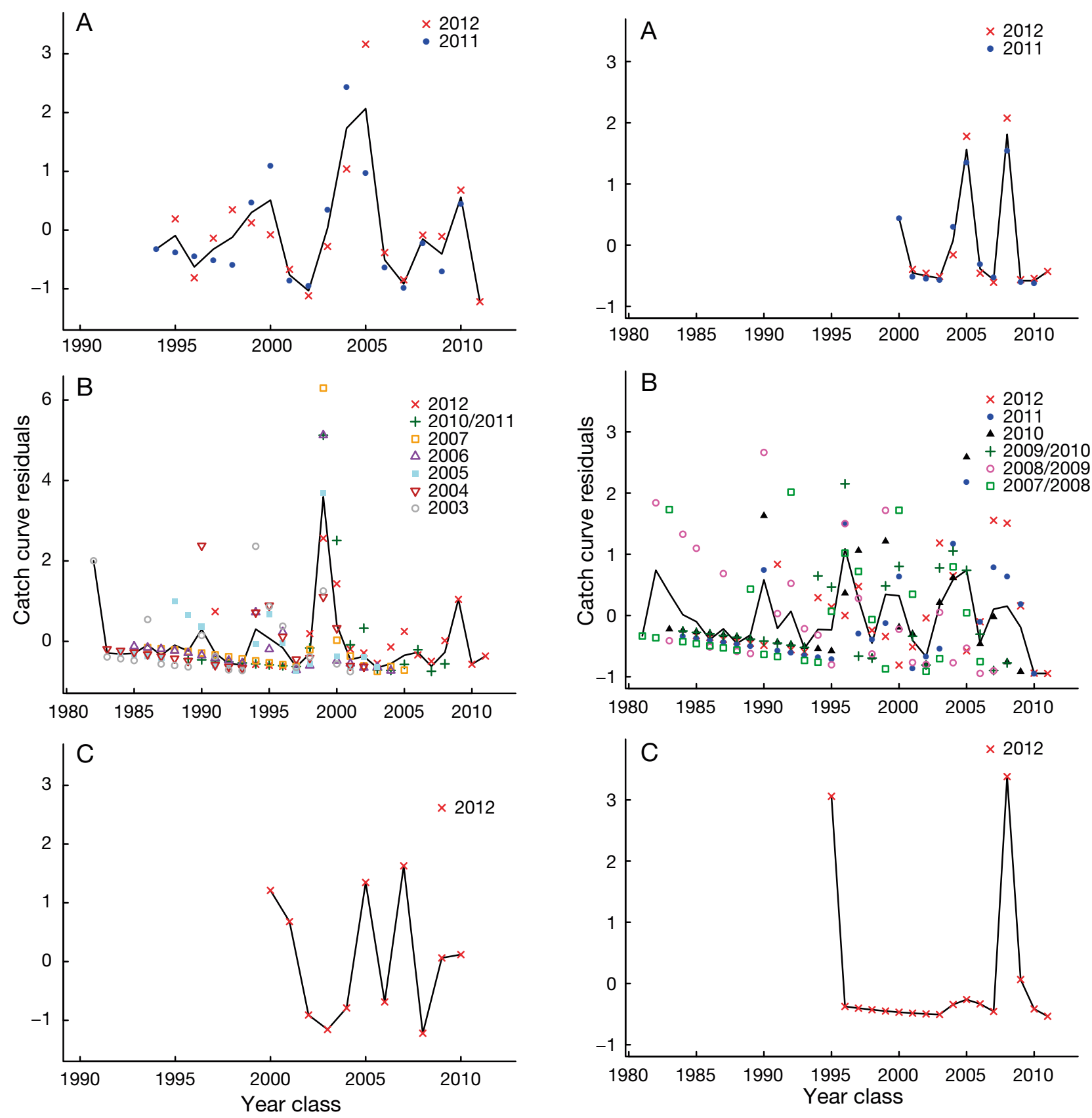

Fig. 8. Pearson residuals (data points) and average of the residuals (solid line) from the negative binomial catch curve regression of the age structure of black bream Acanthopagrus butcheri in the (A) Eumeralla, (B) Hopkins and (C) Snowy Estuaries. Note different $x$ - and $y$-axis scaling in (B)

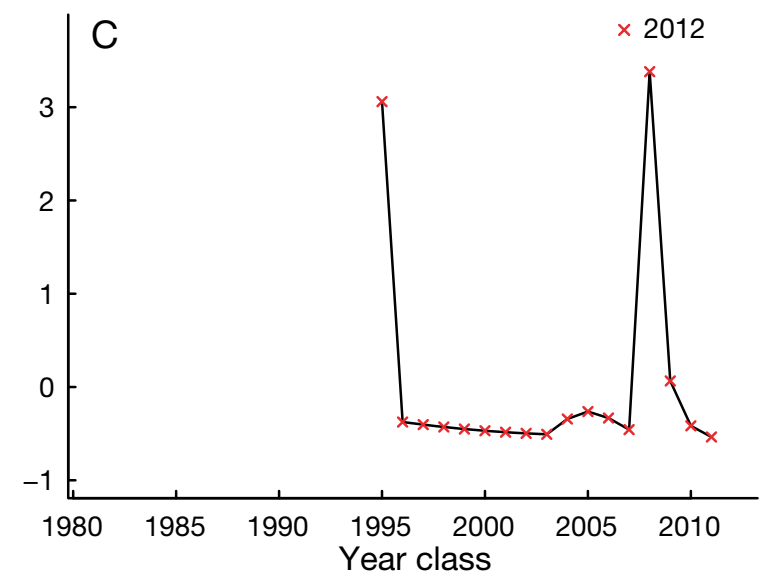

Fig. 9. Standardised residuals (data points) and average of the residuals (solid line) from the catch curve regression of the age structure of estuary perch Macquaria colonorum in the (A) Glenelg, (B) Hopkins and (C) Snowy Estuaries

Recruitment variation based on catch curve residuals was compared amongst the 6 estuaries sampled for black bream using correlation analysis. In the 3 western estuaries, the 2009, 2006, 2003 and 2000 year classes were all strong (Fig. 7). This corresponded with recruitment variation that was significantly correlated amongst the 3 most western estuaries (Glenelg

vs. Surry, $r=0.583, p=0.023$; Glenelg vs. Fitzroy, $r=$ 0.569, $p=0.042$; Surry vs. Fitzroy, $r=0.882, p<0.001$ ), but recruitment was not significantly correlated amongst other estuary combinations ( $p>0.05)$.

Like black bream, catch curve analysis for estuary perch in 3 estuaries showed highly variable recruitment (Fig. 9). In the Glenelg Estuary, peaks in 0+ age 
recruitment occurred in 2008, 2005 and 2000, with low levels of recruitment in other years (Fig. 9A). The Hopkins Estuary data showed considerable amongsample variation in estimates of recruitment variation (Fig. 9B). Nonetheless, high 0+ age recruitment occurred in 2007-2008, 2003-2005, 1996, 1990 and 1982 (Fig. 9B). In the Snowy Estuary the analysis indicated very high $0+$ age recruitment in 2008 and 1995, with very little recruitment occurring in the intervening years (Fig. 9C).

Recruitment variation based on catch curve residuals was compared amongst the 3 estuaries sampled for estuary perch using correlation analysis. Recruitment variation was significantly correlated between the Glenelg Estuary and the Hopkins Estuary ( $\mathrm{r}=$ 0.607, $p=0.036$ ) and the Glenelg Estuary and the Snowy Estuary $(r=0.682, p=0.015)$. There was no correlation among the Hopkins and Snowy Estuaries $(p>0.05)$. The significant correlation between recruitment in the Snowy and Glenelg Estuaries was mainly driven by the dominant 2008 year class in both estuaries (Fig. 9).
In estuaries where both species were sampled (Glenelg, Hopkins, Snowy), there was no significant correlation between the recruitment of the 2 species $(\mathrm{p}>0.05)$.

\section{Relationship between recruitment variability and physical variables}

Black bream

Full results of the black bream recruitmentenvironmental covariate model selection are presented in Tables S1 (short-term flow and salinity) and S2 (long-term flow) in the Supplement (at www.intres.com/articles/suppl/m523p125_supp.pdf) and summarised along with test statistics in Table 3.

In the Glenelg Estuary, there was a strong negative relationship between MDF and the level of stratification, and P10 and stratification at the upper site $(\mathrm{r}=$ $-0.902, t_{5}=4.682, \mathrm{p}=0.005$ and $\mathrm{r}=-0.834, t_{5}=3.383$, $\mathrm{p}=0.020$ respectively) and a positive relationship

Table 3. Response directions and significance (Wald tests) of correlations between recruitment and physical variables (water flow, salinity stratification) for black bream Acanthopagrus butcheri and estuary perch Macquaria colonorum from Victorian estuaries. These best models are derived from AIC-based model selection outlined in Tables S1 to S4 in the Supplement at www.int-res.com/articles/suppl/m523p125_supp.pdf. MDF: mean daily flow; P10: flow exceeded 10\% of the time; upper, middle and lower: water quality monitoring sites 1, 2 and 3 respectively (see Fig. 1); average: mean value for the 3 sites; flow incorporates non-signififcant MDF and P10 terms. Response direction indicates significant $(\mathrm{p}<0.05)$ positive $(+)$ or negative $(-)$ relationship, or no (ns) relationship

\begin{tabular}{|c|c|c|c|c|c|}
\hline Estuary & Species & Variable & Time period & Response direction & Significance \\
\hline Glenelg & $\begin{array}{l}\text { Black bream } \\
\text { Estuary perch }\end{array}$ & $\begin{array}{l}\mathrm{MDF}+\mathrm{MDF}^{2} \\
\text { Flow } \\
\text { Stratification (upper) } \\
\text { MDF }+\mathrm{MDF}^{2} \\
\text { P10 } \\
\text { Stratification (middle) }\end{array}$ & $\begin{array}{l}1992-2010 \\
2003-2010 \\
2004-2010 \\
1999-2010 \\
2004-2010 \\
2004-2010\end{array}$ & $\begin{array}{l}- \text { then }-^{\mathrm{a}} \\
\text { ns } \\
+ \\
+ \text { then - } \\
+ \\
-\end{array}$ & $\begin{array}{l}<0.001,0.005 \\
\text { ns } \\
<0.001 \\
0.005,0.056 \\
<0.001 \\
<0.001\end{array}$ \\
\hline Surry & Black bream & $\begin{array}{l}\text { MDF } \\
\text { Stratification (upper) }\end{array}$ & $\begin{array}{l}1995-2009 \\
2004-2009 \\
2004-2009\end{array}$ & $\begin{array}{l}- \\
- \\
+\end{array}$ & $\begin{array}{l}0.003 \\
0.007 \\
0.003\end{array}$ \\
\hline Fitzroy & Black bream & $\begin{array}{l}\text { MDF } \\
\text { Stratification (lower) }\end{array}$ & $\begin{array}{l}1997-2009 \\
2004-2009 \\
2004-2009\end{array}$ & $\begin{array}{l}- \\
- \\
+\end{array}$ & $\begin{array}{l}0.081 \\
0.003 \\
0.001\end{array}$ \\
\hline Eumeralla & Black bream & $\begin{array}{l}\mathrm{P} 10+\mathrm{P} 10^{2} \\
\text { MDF } \\
\text { Stratification (average) }\end{array}$ & $\begin{array}{l}1993-2010 \\
2004-2010 \\
2004-2011\end{array}$ & $\begin{array}{c}+ \text { then - } \\
- \\
+\end{array}$ & $\begin{array}{l}0.021,0.001 \\
<0.001 \\
<0.001\end{array}$ \\
\hline Hopkins & $\begin{array}{l}\text { Black bream } \\
\text { Estuary perch }\end{array}$ & $\begin{array}{l}\text { MDF } \\
\text { Flow } \\
\text { Stratification (upper) } \\
\text { Flow } \\
\text { Stratification (upper) }\end{array}$ & $\begin{array}{l}1981-2010 \\
2004-2010 \\
2004-2010 \\
1980-2010 \\
2004-2010 \\
2004-2010\end{array}$ & $\begin{array}{c}- \\
\text { ns } \\
- \\
\text { ns } \\
\text { ns } \\
-\end{array}$ & $\begin{array}{l}<0.001 \\
\mathrm{~ns} \\
0.033 \\
\mathrm{~ns} \\
\mathrm{~ns} \\
0.004\end{array}$ \\
\hline Snowy & $\begin{array}{l}\text { Black bream } \\
\text { Estuary perch }\end{array}$ & $\begin{array}{l}\text { MDF } \\
\text { Flow }\end{array}$ & $\begin{array}{l}1999-2009 \\
1994-2010\end{array}$ & $\begin{array}{l}- \\
\mathrm{ns}\end{array}$ & $\begin{array}{l}0.049 \\
\mathrm{~ns}\end{array}$ \\
\hline
\end{tabular}


between P10 and stratification at the lower site ( $\mathrm{r}=$ $0.786, t_{5}=2.685, \mathrm{p}=0.044$ ) between 2004 and 2010 . Over the same period, there was a strong positive relationship between recruitment and increasing stratification in the upper estuary (Table 3, Table S1; $\triangle \mathrm{AIC}$ for null model: 12.86). When the comparison with freshwater flow was extended back to 1992 using all available recruitment data, there was a significant curve-linear negative relationship between MDF and recruitment (Table 3, Table S2; $\triangle \mathrm{AIC}$ for null model: 23.95).

In the Surry Estuary, we found no significant correlations between freshwater flow and stratification between 2004 and 2010. During this period, good black bream recruitment occurred in years with lower MDF and elevated stratification in the upper estuary (Table S1; $\triangle \mathrm{AIC}$ for null model: 8.58). When the comparison was extended back to 1995 using all available recruitment data, there was a significant negative correlation between MDF and recruitment (Table 3, Table S2; $\Delta$ AIC for null model: 5.97).

In the Fitzroy Estuary, there were no significant correlations between freshwater flow and stratification between 2004 and 2010. During this period, black bream recruitment was negatively related to MDF and positively related to stratification in the lower estuary (Table 3, Table S1; $\triangle \mathrm{AIC}$ for null model: 9.26). Over the longer term back to 1997 , there was a weak negative correlation between MDF and recruitment (Table 3 , Table S2; $\Delta$ AIC for null model: 0.96).

In the Eumeralla Estuary, MDF was significantly and positively correlated with lower site stratification $\left(\mathrm{r}=0.798, t_{5}=2.60, \mathrm{p}=0.032\right)$ and with stratification averaged across sites between 2004 and 2010 ( $\mathrm{r}=$ $0.780, t_{5}=2.791, \mathrm{p}=0.032$ ). Over the same period, there was a significant negative relationship between recruitment and MDF and a positive relationship between recruitment and average estuary stratification (Table 3, Table S1; $\Delta$ AIC for null model: 18.10). When the comparison with freshwater flow was extended back to 1993 using all available recruitment data, there was a significant curve-linear relationship between P10 and recruitment (Table 3, Table S2; $\Delta$ AIC for null model: 3.24), with recruitment initially increasing with high flows and then decreasing.

In the Hopkins Estuary, there were no significant correlations between freshwater flow and stratification between 2004 and 2010. Over this period, recruitment showed a weak negative relationship to stratification in the upper estuary (Table 3, Table S1; $\triangle \mathrm{AIC}$ for null model: 1.46). When the comparison was extended back to 1981 using all available recruit- ment data, there was a significant negative correlation between MDF and recruitment (Table 3, Table S2; $\triangle$ AIC for null model: 22.81).

In the Snowy Estuary, we found a negative correlation between black bream recruitment and MDF from 1999 to 2009 (Table 3, Table S2; $\Delta$ AIC for null model: 2.13).

\section{Estuary perch}

Full results of estuary perch recruitment-environmental covariate model selection are presented in Tables S3 (short-term flow and salinity) and S4 (longterm flow) in the Supplement and summarised along with test statistics in Table 3.

As for black bream, there was a strong correlation between freshwater flow and stratification between 2004 and 2010 in the Glenelg estuary. Over the same period, estuary perch recruitment was positively related to P10 and negatively related to stratification in the middle estuary (Table 3 , Table S3; $\triangle \mathrm{AIC}$ for null model: 18.44) When the comparison with freshwater flow was extended back to 1999 using all available recruitment data, there was a curve-linear relationship between MDF and recruitment (Table 3, Table S4; $\triangle \mathrm{AIC}$ for null model: 0.57); recruitment initially increasing with MDF then beginning to decline.

In the Hopkins estuary between 2004 and 2010, we found a negative relationship between recruitment and stratification in the upper estuary (Table 3, Table S3; $\triangle \mathrm{AIC}$ for null model: 5.81). When the comparison was extended back to 1980 using all available recruitment data, there was no significant correlation with freshwater flow (Table S4).

In the Snowy estuary, there was no relationship between estuary perch recruitment and flow from 1994 to 2009 (Table S4).

\section{Summary}

In summary, black bream recruitment over the short and/or longer term was negatively correlated to flow (MDF or P10) in all 6 estuaries. Black bream recruitment was also positively related to estuary stratification in 4 of 5 estuaries with data (but negative in Hopkins). Estuary perch recruitment showed the opposite pattern: it was positively related to flow (MDF or P10) in only 1 of 3 relevant estuaries, but was also negatively related to stratification in both estuaries with data. 


\section{Re-assessment of results from Gippsland Lakes}

Like in many systems in the present study, a strong positive correlation was found between recruitment of black bream and stratification in Gippsland Lakes (Jenkins et al. 2010); however, this correlation related to $0+$ juveniles of 6 to 12 mo age rather than eggs and larvae as was assumed at the time. When the recruitment estimated from annual recruitment monitoring in Gippsland Lakes (Jenkins et al. 2010) was re-analysed with a $1 \mathrm{yr}$ lag in the recruitment estimates to take the relationship back to the spawning year, a significant negative relationship with stratification in the Lakes was found $\left(\mathrm{R}=0.671, F_{1,9}=7.363\right.$, $\mathrm{p}=0.024)$.

\section{DISCUSSION}

Both black bream and estuary perch showed highly variable recruitment in this study. This is consistent with previous studies on black bream in Gippsland Lakes (Morison et al. 1998, Jenkins et al. 2010) and estuary perch in the Bemm River, Victoria (Walsh et al. 2010, Morrongiello et al. 2014). This episodic recruitment suggests that suitable conditions for spawning and survival from egg to larvae to juveniles occurs on an infrequent basis, reflecting variability in the estuarine environment.

The influence of broad-scale climatic factors such as rainfall on recruitment variability in these species was suggested by the similarity in recruitment patterns for black bream in the 3 most western Victorian estuaries, and the similarity in recruitment of estuary perch between the Glenelg Estuary and both the Snowy and Hopkins Estuaries. On the other hand, local-scale influences were suggested by the fact that other estuaries show unique recruitment patterns, for example the Eumeralla and Hopkins Estuaries for black bream. The results clearly showed that recruitment patterns for black bream and estuary perch were different across the estuaries studied, suggesting the environmental requirements of the 2 species for successful recruitment are also different.

Considering that the inflows to estuaries were relatively similar, there was considerable variation in the characteristics of salinity stratification amongst the estuaries over the July to December period. These differences reflect the interaction of inflows with the topography and bathymetry of the estuary, and also the estuary mouth opening characteristics (Roy et al. 2001, Potter et al. 2010).
In the case of black bream, higher recruitment was most consistently related to reduced freshwater flows and increased stratification. Black bream eggs and larvae are most concentrated in the halocline of a highly stratified water column (Nicholson et al. 2008, Williams et al. 2013). Stratified conditions in the salt wedge are areas of high productivity of zooplankton prey for fish larvae (Sirois \& Dodson 2000, North \& Houde 2001, 2003, Shoji et al. 2005), thereby possibly enhancing the survival of larval bream. Recent sampling of the Mitchell River, Gippsland Lakes, has shown high concentrations of zooplankton prey associated with the highly stratified area of the salt wedge in areas of highest abundance of larval black bream (Williams et al. 2012, 2013). In contrast, black bream in the Swan Estuary, Tasmania, spawn upstream in low flow conditions in the absence of strong water column stratification (Sakabe \& Lyle 2010, Sakabe et al. 2011).

In contrast to black bream, higher recruitment of estuary perch was related to years of lower stratification and in one estuary to years with increased freshwater flow. This result is consistent with the finding that estuary perch recruitment was positively related to freshwater flows in the Bemm River, eastern Victoria (Morrongiello et al. 2014). The positive relationship with recruitment of estuary perch and freshwater flow and the negative relationship with stratification is consistent with greater movement of estuary perch to lower estuary spawning grounds in periods of higher flow and reduced salinity (Walsh et al. 2013). This downstream movement for spawning under high flow conditions for estuary perch reflects the reproductive behaviour of the congeneric Australian bass Macquaria novemaculeata (Harris 1986). This is a freshwater species, but downstream catadromous migration occurs during floods for spawning in the upper estuary (salinity 8 to 14) (Harris 1986).

The mechanism for increased recruitment of estuary perch in years of increased freshwater flow and reduced stratification is unknown, mainly because of our poor knowledge of the biology of this species. Trnski et al. (2005) collected estuary perch larvae entering a central New South Wales estuary from the ocean on a flood tide, suggesting that larvae were potentially dispersed into the sea after spawning. This dispersal from spawning areas near the mouths of estuaries would be enhanced under conditions of high freshwater flow (and high flow may be required to open the estuary mouth in some systems). Another possible advantage of spawning under higher flow conditions would be that areas of low dissolved oxy- 
gen formed under low-flow and highly stratified conditions would be flushed from the system (Newton 1996).

\section{Re-assessment of results from Gippsland Lakes}

The updated analysis showed higher recruitment of black bream in Gippsland Lakes when stratification in the Lakes was reduced in the year of spawning. This means that we must re-assess the originally proposed hypothesis of egg and larval survival being high when the Gippsland Lakes are stratified, because suitable spawning and larval survival conditions expanded beyond the feeder rivers (Jenkins et al. 2010). Stratification in Gippsland Lakes is positively related to freshwater flows (similar to the Eumeralla Estuary in western Victoria) and stratification is reduced when flows decrease and conditions in the Lakes become more marine like. Recent work from the Gippsland Lakes has shown that successful spawning and larval survival of black bream occurs in the salt wedge in feeder rivers under relatively low-flow conditions (Williams et al. 2012, 2013). Thus, successful recruitment when lower stratification occurs in the Lakes is likely to correspond to higher stratification in the feeder rivers where spawning occurs, consistent with the results for black bream from western Victoria in the present study. This result is also similar to previous analyses of black bream recruitment in the Gippsland Lakes, showing that dominant year classes were associated with low river flow in October during the spawning period (Hobday \& Moran 1983, Walker et al. 1998).

The positive relationship between recruitment of black bream in Gippsland Lakes and stratification found by Jenkins et al. (2010) was for juveniles in the year following spawning. This indicates that freshwater flows leading to increased stratification in the Lakes in the early juvenile stage had a positive effect on recruitment. A possible mechanism that could explain the higher recruitment of black bream when significant freshwater flows occur in the year following spawning is that this higher flow may increase the available habitat for juveniles in their first year of life by allowing them to spread from rivers into lakes where extensive seagrass beds occur. The positive correlation between flows in the year after spawning and abundance of $0+$ juveniles found in the reassessment of Gippsland Lakes results is supported by a previous analysis that showed a positive correlation between rainfall in the May after spawning and year class strength of black bream in Gippsland
Lakes (Walker et al. 1998). These results suggest a possible 2-phase mechanism leading to high recruitment in the Gippsland Lakes, where successful spawning and larval survival occur in the salt wedge in feeder rivers under relatively low-flow conditions (Williams et al. 2012, 2013), but are then followed by higher freshwater flow in the year that would facilitate downstream movement of late-stage larvae or post-settlement juveniles to areas of suitable habitat in the lakes (e.g. seagrass).

\section{Implications of climate change for recruitment}

A key result from this study is that 2 important estuarine fish species with high levels of recruitment variability and similar spawning periods show evidence of different requirements in terms of freshwater flow and stratification for successful recruitment. Strong year classes of black bream tend to be associated with reduced freshwater flows and higher salinity stratification over the spawning period while for estuary perch higher recruitment occurs in years of higher flow and reduced salinity stratification over the spawning period. For black bream the situation may be more complicated in the Gippsland Lakes, with strong year classes apparently resulting from a 2-phase mechanism where low freshwater flow occurs over the spawning season and then is followed by higher flows after the spawning season during the first year of juvenile life.

As a result of this postulated divergence in environmental requirements, significant inter-annual variability in the flow regime may be required to provide favourable conditions for recruitment of both species in some systems. This inter-annual variability is driven by multiple major atmospheric-oceanic drivers that lead to high interannual variability in rainfall and freshwater flows (CSIRO 2010, Chiew et al. 2011). These 2 species are well adapted to this variability through their longevity (over $30 \mathrm{yr}$ ) and ability to produce strong year classes on an episodic basis when conditions are suitable (Morison et al. 1998, Jenkins et al. 2010, Walsh et al. 2010).

Climate change is likely to result in both a reduction and a seasonal shift in the amount of freshwater flow entering Victorian estuaries (CSIRO 2010, Chiew et al. 2011, Hobday \& Lough 2011). Freshwater runoff will be reduced through the effects of reduced rainfall, and of increased solar radiation and decreased humidity leading to increased evaporation rates (CSIRO 2007). The seasonal shift will see a marked reduction in the rainfall and associated flows 
over the winter period but little reduction in rainfall over the summer to autumn period, although rainfall events over this period will become more intermittent and intense (CSIRO 2007).

Based on the results of this study, these changes may be more favourable for black bream but less favourable for estuary perch populations in Victoria. Black bream will be favoured by lower flows over the spawning period leading to salt wedge development and stratification. In the Gippsland Lakes, the fact that flows will not greatly decline in the autumn period should limit the negative effect of climate change, although the impact of flow events becoming more intermittent and intense over this period is unknown. In contrast, our results suggest that lower flows over the spring spawning period of estuary perch will be less favourable for recruitment in most systems. Low winter and spring flows may be beneficial for black bream in maintaining the stratified salt wedge, but if flows become too low then conditions may deteriorate where the upstream advance of the salt wedge is blocked by stream barriers (Williams et al. 2013).

In conclusion, climate change is likely to result in conditions more favourable to some species but less to others amongst estuarine and marine species (Fulton 2011, Bell et al. 2013, Dutkiewicz et al. 2013), including fish (Graham \& Harrod 2009, Milazzo et al. 2013). Our study indicates that conditions for recruitment of black bream in south-eastern Australia may generally become more favourable, while for estuary perch they may become less favourable under climate change. The results of this study show that there is no single flow level or narrow range of flow levels that can be set to maintain resilience of fish species in these systems. The resilience of these 2 species relies on the maintenance of inter-annual variability in flows so that suitable conditions of recruitment of both species will occur frequently enough for populations to be supported. Under climate change, there will be an overall reduction in flows in the winter; in the case of estuary perch, it may be critical to ensure that significant flows occur over this period in some years.

Acknowledgements. We thank the Glenelg Hopkins Catchment Management Authority for providing physico-chemical data for the west Victorian estuaries. We thank Lauren Brown and Guy Werner for assistance with research netting and also the many anglers who assisted with providing specimens in the angler diary and research angler programmes. We thank the staff of Fish Ageing Services for ageing otoliths from research netting and recreational angling. We acknowledge the funding for this work provided by the
Future Farming Strategy Initiative on climate change adaptation for the State Government of Victoria.

\section{LITERATURE CITED}

Arthington AH, Pusey BJ (2003) Flow restoration and protection in Australian rivers. River Res Appl 19:377-395

Barton JL, Pope AJ, Quinn GP, Sherwood JE (2008) Identifying threats to the ecological condition of Victorian estuaries. Technical Report. Department of Sustainability and Environment, Melbourne

Bell JD, Ganachaud A, Gehrke PC, Griffiths SP and others (2013) Mixed responses of tropical Pacific fisheries and aquaculture to climate change. Nat Clim Change 3: 591-599

Burnham KP, Anderson DR (2002) Model selection and multimodel inference: a practical information-theoretic approach, 2nd edn. Springer, New York, NY

$>$ Chiew FHS, Young WJ, Cai W, Teng J (2011) Current drought and future hydroclimate projections in southeast Australia and implications for water resources management. Stochastic Environ Res Risk Assess 25:601-612

Chuwen BM, Hoeksema SD, Potter IC (2009) The divergent environmental characteristics of permanently-open, seasonally-open and normally-closed estuaries of southwestern Australia. Estuar Coast Shelf Sci 85:12-21

CSIRO (Commonwealth Scientific and Industrial Research Organisation) (2007) Climate change in Australia. CSIRO and Australian Bureau of Meterorology, www.climate changeinaustralia.gov.au/, accessed July 2013

CSIRO (2010) Climate variability and change in south-eastern Australia: a synthesis of findings from Phase 1 of the South Eastern Australian Climate Initiative (SEACI). CSIRO, Clayton South

> Deegan LA (1990) Effects of estuarine environmental conditions on population dynamics of young-of-the-year gulf menhaden. Mar Ecol Prog Ser 68:195-205

Douglas J (2010) Estuary perch movement and habitat use in the Snowy River. Recreational Fishing Grant Program, Research report. Fisheries Victoria, Melbourne

> Dutkiewicz S, Scott JR, Follows MJ (2013) Winners and losers: ecological and biogeochemical changes in a warming ocean. Global Biogeochem Cycles 27:463-477

Fulton EA (2011) Interesting times: winners, losers, and system shifts under climate change around Australia. ICES J Mar Sci 68:1329-1342

Gillanders BM, Elsdon TS, Halliday IA, Jenkins GP, Robins JB, Valesini FJ (2011) Potential effects of climate change on Australian estuaries and fish utilising estuaries: a review. Mar Freshw Res 62:1115-1131

> Graham CT, Harrod C (2009) Implications of climate change for the fishes of the British Isles. J Fish Biol 74:1143-1205

Griffiths SP (1999) Consequences of artificially opening coastal lagoons on their fish assemblages. Int J Salt Lake Res 8:307-327

Griffiths SP, West RJ (1999) Preliminary assessment of shallow water fish in three small intermittently open estuaries in southeastern Australia. Fish Manag Ecol 6:311-321

> Haddy JA, Pankhurst NW (1998) Annual change in reproductive condition and plasma concentrations of sex steroids in black bream, Acanthopagrus butcheri (Munro) (Sparidae). Mar Freshw Res 49:389-397

> Haddy JA, Pankhurst NW (2000) The effects of salinity on reproductive development, plasma steroid levels, fertili- 
sation and egg survival in black bream Acanthopagrus butcheri. Aquaculture 188:115-131

> Halliday IA, Robins JB, Mayer DG, Staunton-Smith J, Sellin MJ (2008) Effects of freshwater flow on the year-class strength of a non-diadromous estuarine finfish, king threadfin (Polydactylus macrochir), in a dry-tropical estuary. Mar Freshw Res 59:157-164

- Harris J (1986) Reproduction of the Australian bass, Macquaria novemaculeata (Perciformes: Percichthyidae) in the Sydney Basin. Aust J Mar Freshw Res 37:209-235

Hobday AJ, Lough JM (2011) Projected climate change in Australian marine and freshwater environments. Mar Freshw Res 62:1000-1014

Hobday D, Moran M (1983) Age, growth and fluctuating year-class strength in black bream in the Gippsland Lakes, Victoria. Report No. 20, Marine Science Laboratories, Ministry for Conservation, Victoria

> Jenkins GP, Conron SD, Morison AK (2010) Highly variable recruitment in an estuarine fish is determined by salinity stratification and freshwater flow: implications of a changing climate. Mar Ecol Prog Ser 417:249-261

> Kimmerer WJ (2002) Physical, biological, and management responses to variable freshwater flow into the San Francisco Estuary. Estuaries 25:1275-1290

Kimmerer WJ, Cowan JH Jr, Miller LW, Rose KA (2001) Analysis of an estuarine striped bass population: effects of environmental conditions during early life. Estuaries 24:557-575

King M (2007) Fisheries biology, assessment and management. Blackwell Publishing, Oxford

> Kurup GR, Hamilton DP, Patterson JC (1998) Modelling the effect of seasonal flow variations on the position of salt wedge in a microtidal estuary. Estuar Coast Shelf Sci 47: 191-208

> Maceina MJ (1997) Simple application of using residuals from catch-curve regressions to assess year-class strength in fish. Fish Res 32:115-121

> Milazzo M, Mirto S, Domenici P, Gristina M (2013) Climate change exacerbates interspecific interactions in sympatric coastal fishes. J Anim Ecol 82:468-477

> Morison AK, Coutin PC, Robertson SG (1998) Age determination of black bream, Acanthopagrus butcheri (Sparidae), from the Gippsland Lakes of south-eastern Australia indicates slow growth and episodic recruitment. Mar Freshw Res 49:491-498

> Morrongiello JR, Walsh CT, Gray CA, Stocks JR, Crook DA (2014) Environmental change drives long-term recruitment and growth variation in an estuarine fish. Glob Change Biol 20:1844-1860

> Newton GM (1996) Estuarine ichthyoplankton ecology in relation to hydrology and zooplankton dynamics in a salt-wedge estuary. Mar Freshw Res 47:99-111

> Nicholson G, Jenkins GP, Sherwood J, Longmore A (2008) Physical environmental conditions, spawning and earlylife stages of an estuarine fish: climate change implications for recruitment in intermittently open estuaries. Mar Freshw Res 59:735-749

> North EW, Houde ED (2001) Retention of white perch and striped bass larvae: biological-physical interactions in Chesapeake Bay estuarine turbidity maximum. Estuaries 24:756-769

North EW, Houde ED (2003) Linking ETM physics, zooplankton prey, and fish early-life histories to striped bass Morone saxatilis and white perch $M$. americana recruitment. Mar Ecol Prog Ser 260:219-236
North EW, Hood RR, Chao SY, Sanford LP (2005) The influence of episodic events on transport of striped bass eggs to the estuarine turbidity maximum nursery area. Estuaries 28:108-123

> Potter IC, Chuwen BM, Hoeksema SD, Elliott M (2010) The concept of an estuary: a definition that incorporates systems which can become closed to the ocean and hypersaline. Estuar Coast Shelf Sci 87:497-500

Quinn GP, Keough MJ (2002) Experimental design and data analysis for biologists. Cambridge University Press, Cambridge

Robins JB, Halliday IA, Staunton-Smith J, Mayer DG, Sellin MJ (2005) Freshwater-flow requirements of estuarine fisheries in tropical Australia: a review of the state of knowledge and application of a suggested approach. Mar Freshw Res 56:343-360

> Roy PS, Williams RJ, Jones AR, Yassini I and others (2001) Structure and function of south-east Australian estuaries. Estuar Coast Shelf Sci 53:351-384

> Rulifson RA, Manooch CS III (1990) Recruitment of juvenile striped bass in the Roanoke River, North Carolina, as related to reservoir discharge. N Am J Fish Manage 10: 397-407

Sakabe R, Lyle JM (2010) The influence of tidal cycles and freshwater inflow on the distribution and movement of an estuarine resident fish Acanthopagrus butcheri. J Fish Biol 77:643-660

> Sakabe R, Lyle JM, Crawford CM (2011) The influence of freshwater inflows on spawning success and early growth of an estuarine resident fish species, Acanthopagrus butcheri. J Fish Biol 78:1529-1544

Sarre GA, Potter IC (2000) Variation in age composition and growth rates of Acanthopagrus butcheri (Sparidae) among estuaries: some possible contributing factors. Fish Bull 98:785-799

Scavia D, Field J, Boesch D, Buddemeier R and others (2002) Climate change impacts on U.S. coastal and marine ecosystems. Estuaries 25:149-164

Sherwood J, Mondon J, Fenton C (2008) Classification and management issues of estuaries in Western Victoria, Australia. Proc R Soc Vic 120:257-276

Shoji J, North EW, Houde ED (2005) The feeding ecology of Morone americana larvae in the Chesapeake Bay estuarine turbidity maximum: the influence of physical conditions and prey concentrations. J Fish Biol 66:1328-1341

Shoji J, Ohta T, Tanaka M (2006) Effects of river flow on larval growth and survival of Japanese seaperch Lateolabrax japonicus (Pisces) in the Chikugo River estuary, upper Ariake Bay. J Fish Biol 69:1662-1674

Sirois P, Dodson JJ (2000) Influence of turbidity, food density and parasites on the ingestion and growth of larval rainbow smelt Osmerus mordax in an estuarine turbidity maximum. Mar Ecol Prog Ser 193:167-179

Staunton-Smith J, Robins JB, Mayer DG, Sellin MJ, Halliday IA (2004) Does the quantity and timing of fresh water flowing into a dry tropical estuary affect year-class strength of barramundi (Lates calcarifer)? Mar Freshw Res 55:787-797

Trnski T, Hay AC, Fielder DS (2005) Larval development of estuary perch (Macquaria colonorum) and Australian bass ( $M$. novemaculeata) (Perciformes: Percichthyidae), and comments on their life history. Fish Bull 103:183-194

Walker S, Sporcic M, Coutin P (1998) Development of an environment-recruitment model for black bream: a case study for estuarine fisheries management. Report No. 
96/102, Fisheries Research and Development Corporation, Canberra

Walsh CT, Gray CA, West RJ, van der Meulen DE, Williams LFG (2010) Growth, episodic recruitment and age truncation in populations of a catadromous percichthyid, Macquaria colonorum. Mar Freshw Res 61:397-407

Walsh CT, Gray CA, West RJ, Williams LFG (2011) Reproductive biology and spawning strategy of the catadromous percichthyid, Macquaria colonorum (Günther, 1863). Environ Biol Fishes 91:471-486

Walsh CT, Reinfelds IV, Ives MC, Gray CA, West RJ, van der Meulen DE (2013) Environmental influences on the

Editorial responsibility: Charles Peterson,

Morehead City, North Carolina, USA spatial ecology and spawning behaviour of an estuarineresident fish, Macquaria colonorum. Estuar Coast Shelf Sci 118:60-71

Williams J, Hindell JS, Swearer SE, Jenkins GP (2012) Influence of freshwater flows on the distribution of eggs and larvae of black bream Acanthopagrus butcheri within a drought-affected estuary. J Fish Biol 80:2281-2301

Williams J, Jenkins GP, Hindell JS, Swearer SE (2013) Linking environmental flows with the distribution of black bream Acanthopagrus butcheri eggs, larvae and prey in a drought affected estuary. Mar Ecol Prog Ser 483: 273-287

Submitted: September 26, 2013; Accepted: November 28, 2014 Proofs received from author(s): February 24, 2015 